\title{
A Product of Software Patents
}

\author{
Kent R Acheson* \\ Kaplan University, USA \\ Submission: July 08, 2016; Published: July 14, 2016 \\ *Corresponding author: Kent Acheson, Kaplan University, 8601 S Mingo Rd, \#6103, Tulsa, OK 74133, USA, Tel: 918-629-1989; \\ Email: drkentraymon@gmail.com
}

\section{A Product of Software Patents}

A new software program is available. The company has been advertising and elevating anticipation in public circles for eight months or more about all the new features and increased productivity available. But there is nothing breath-taking about it. The only improved functionality seems sequential and incremental over the last version nothing new or unique and in fact, obvious which are the requirements for a patent. The software company however, received 10 new patents on the program, which last 20 -years each. The product will be obsolete in a year, but the company can sue for patent infringement and collect royalties or licensing fees from anyone who uses the ideas or tries to improve the software program.

Big Software began pushing for reform legislation to limit the number of patent infringement lawsuits, and therefore, the amounts paid in damages [1]. Smaller software companies and innovative companies agree that for most tech companies patents are not important, and most big software companies ignore the patent system anyway saying "[patents have] never been a way to make money" [2].

Defensive patenting by software companies explains if a company holds enough patents then this company can steal another product company's ideas with impunity, but the problem enters when the other entity does not create a product to attack.

Technology companies exaggerate the problem when over the last 20 years patents have remained in last place of lawsuits for the three forms of idea protection: trademark, copyright and patents. A study of four high-tech companies that are active in the patent reform debate paid out $\$ 3.7$ billion in patent lawsuit settlement from 1993 to 2005, but those same four companies earned \$1.4 trillion in revenue over the same period making the sums for infringement only $0.26 \%$ of revenues on average. The company with the highest number of lawsuits experienced sums for infringement at only $0.51 \%$ of revenues [3].

The larger software enterprises that often infringe on patents held by companies that do not produce a product (patent trolls) behave similarly as these same companies (patent trolls). IBM and Microsoft sit on patents without an accompanying products and then when another company discovers something similar, either
IBM or Microsoft will spring a patent on the unsuspecting company and demand licensing or royalty fees from that company to avoid costly litigation [4]; thus like the Troll to cross the bridge. IBM earned over a billion dollars in 2005 solely from license agreements and royalties. Licensing and royalty agreements are another possible direction that companies take to avoid patent infringement suits. However, their use threatens other companies to ransom licensing or royalty agreements but is cheaper and the outcome more certain than litigation [5].

Google's Android Software in the Samsung Galaxy mobile phone pays royalties to Microsoft because Microsoft mentioned patent infringement of some of Google's OS. Google decided to pay the Troll instead of costly injunctions and delays in sales. This is the price of doing business in a short-lifecycle product where an injunction of just a few months can cost millions of dollars.

Myhrovold [6] shared his experience working for Microsoft in the late 90s stating that large software companies are not concerned with infringing on another's patents and the only reason they care at all about patents is to defend against patent infringement lawsuits. Patents are not how software companies protect innovation but, rather secrecy and lead time or economies of scale are more effective to protect innovation in a short product lifecycle industry.

The Software Industry does not use the patent system to protect intellectual property but rather they use the patent system for defensive purposes; not so much to protect innovation but to defend against infringement lawsuits. Patent Assertion Entities (PAE) previously known as NPE (Non-Practicing Entities) or "patent trolls," are companies only in business to purchase patents then demand royalties from people or companies that infringe on those patents [7]. A wrongly issued patent has negative consequences no matter who receives it. These wrongly issued patents can take the form of poorly defined or too broadly issued patents and theoretically, the court system will better define and solve the associated problems; but, if the case never makes it to court because of the delays involved. This can cause serious problems.

Software companies use patents for defensive purposes to protect themselves from being sued [8]. They will try to threaten 


\section{Organic and Medicinal Chemistry International Journal}

a lawsuit or negotiate a license agreement with the other company who is otherwise infringing or competing against them, but a PAE produces nothing, so software has no leverage and feels vulnerable. According to Chien [9], 51\% of patent suits in 2012 were against non-tech companies and 49\% were tech companies and this was the impetuous for House Judiciary Subcommittee on Courts to reintroduce the SHIELD Act or Saving High-Tech Innovators from Egregious Legal Disputes Act of 2013 (H.R. 845 of the $113^{\text {th }}$ Congress $1^{\text {st }}$ Session). Of course, it is stated this Act will only affect corporate PAEs, not individual inventors or universities. The problem with this implication of "tech" versus "non-tech" companies is that $100 \%$ of the cases listed are for software or software related patent claims, hence the long-name Saving High-Tech Innovators.

The company may not be a "tech company," but the patent infringement is. The irony in this behavior is also that big software companies exhibit the same behaviors the corporate trolls. The only difference is the software companies have a product and will avoid the penalties of HR 845. The reason for the SHIELD Act is to theoretically shift fees from the "little guy" to the "big guy," that is, small start-ups to corporations. To see the details of the Bill and possible loopholes from a more legal perspective, please view Michael Risch's summary titled Scratching My Head Over the SHIELD Act on madisonian.net.

As Acheson [10] suggested in A Study of the Need to Change United States Patent Policy, software should not be patented, but the Intellectual Property Rights should be protected in another manner that does not entail a Copyright, Trademark or secrecy. A new form of protection should be created based on certain criteria such as useful life of a patent, incremental innovation, value to society and/ or value to life.
Congress should devise a shorter-term idea protection specifically for the sequential or disruptive innovation, but not on the product. The protection should be 3 to 5 years. It should enable technological advancement and license agreements. There may be as in other developed countries, a mandated licensing agreement for some critical healthcare oriented medicines, biotechnologies or other such discoveries that will benefit society. Perhaps, by the use of government funding through tax breaks or tax forgiveness.

\section{References}

1. Kent R Acheson (2012) A Study of the Need to Change U.S. Patent Policy. University of Phoenix.

2. Mark Blaxill and Ralph Eckardt (2009) "Witness Testimony for the Innovation Imperative" in US Senate on Patent Reform in the 111th Congress: Legislation and recent court decisions. Washington, DC, USA.

3. Nathan Myhrovold (2006) "Witness Testimony for Intellectual Ventures," in US Senate on post-grant review Washington, DC, USA.

4. Kathleen D. Jaeger (2009) "Witness Testimony for Generic Pharmaceutical Association," in US Senate on Patent Reform in the $111^{\text {th }}$ Congress: Legislation and recent court decisions. Washington, DC, USA.

5. Doyle ME (2007) "Witness Testimony from Palm, Inc.," in US Senate on Patent Reform: The future of American innovation Washington, DC.

6. Myhrovold, "Witness Testimony for Intellectual Ventures."

7. Carrier MA (2013) "Patent Assertion Entities: Six Actions the Antitrust Agencies Can Take," CPI Antitrust Chronicle 1, no. 2, Colleen V. Chien, "Patent Trolls by the Numbers," http://ssrn.com/abstract=2233041; Catherine Tucker, "Patent Trolls and Technology Diffusion," in TILEC Discussion Paper No. 2012-030 (SSRN, 2012).

8. Acheson, "A Study of the Need to Change U.S. Patent Policy."

9. Chien, "Patent Trolls by the Numbers".

10. Acheson, "A Study of the Need to Change U.S. Patent Policy." 